Dorota Maj

UMCS, Lublin

\title{
LOCAL DIRECT DEMOCRACY IN LITHUANIA, LATVIA AND ESTONIA: A COMPARATIVE STUDY
}

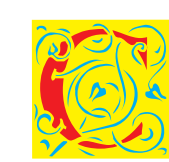

ontemporary democracies, adopting the principle of sovereignty of the nation as a collective sovereign, commonly implement model of representative democracy in which power is exercised through representatives elected in democratic elections. It should be noted that the institutions of direct democracy complement representative democracy. These two types of democracy have their supporters and opponents. On the one hand, it is emphasized that the solutions specific to representative democracy allow to simplify and speed up decision-making processes. Another argument in favor of representative democracy is insufficient knowledge of citizens in public affairs. In turn, supporters of direct democracy emphasize that it is essential to involve citizens in the decision-making process. This type of solutions allows for raising the competence of citizens and improves the quality of governance. For these reasons the European countries are trying to implement both models of democracy.

The best practices in the field of direct democracy have been adopted in Switzerland. The vast majority of the Western European countries have regulations allowing the use of direct democracy. The countries of the Central and Eastern Europe after the initiation of processes of political transformation in the late 1980s have changed their internal laws and incorporated the use of direct democracy. Moreover, the states of the Central and Eastern Europe, which acceded to the European Union in 2004, had conducted the accession referenda. ${ }^{1}$

This paper considers the issue of a local direct democracy in the Baltic countries: Lithuania, Latvia and Estonia. Referendum is the most popular

${ }^{1}$ M. Musiał-Karg, Referenda w państwach europejskich, Toruń: Wydawnictwo Adam Marszałek, 2008, 49. 
institution of direct democracy and it is often identified with the concept of direct democracy. ${ }^{2}$ Andrzej Krasnowolski points out that Lithuania, Latvia and Estonia are countries with the shaping practice of referendums, in which the national referendum was conducted at least five times. ${ }^{3}$ Other institutions of direct democracy include popular initiative, popular referendum and consultations. The main research aim is the analysis of formal and practical dimensions of local direct democracy in the Baltic countries. The analysis of legal acts shows that the institution of direct democracy at the local level is not popular in Lithuania, Latvia and Estonia. Reasons for this are the consequence of the administrative reform and difficulty in filling the formal requirements.

\section{The legal basis of direct democracy in Lithuania, Latvia and Estonia}

The tradition of direct democracy in Lithuania, Latvia and Estonia dates back to the twenties of the $20^{\text {th }}$ century. National constitutions provided a referendum to resolve the most important matters of the State, such as changing the political system or submitting amendments to the constitution. In the interwar period the referendum was conducted in Latvia in 1922, and in Lithuania in 1938. In addition, during this period another institution of direct democracy - optional legislative referendum, constitutive initiative, legislative initiative and parliamentary plebiscite - had been used in Estonia.

The principles of direct democracy in the Baltic countries are laid down in the national constitutions and other legal texts. For example, the legal basis of direct democracy in Lithuania is contained in the Constitution adopted by citizens of the Republic of Lithuania in the referendum on 25 October 1994 and the Lithuanian Republic Law on Referendum which was adopted by the Lithuanian Seimas (the Lithuanian Parliament) on 4 June 2002. The Constitution of the Republic of Lithuania stipulates that the power in Lithuania may be exercised in two ways: directly by the people

2 M. Marczewska-Rytko, Demokracja bezpośrednia w teorii i praktyce politycznej, Lublin: Wydawnictwo Uniwersytetu Marii Curie-Skłodowskiej, 2001, 110.

3 A. Krasnowolski, Referendum jako instytucja demokracji bezpośredniej w państwach europejskich, Warszawa: Kancelaria Sejmu, Biuro Analiz i Dokumentacji, 2016, 10. 
or indirectly through democratically elected representatives. ${ }^{4}$ Regulations concerning the referendum on the national level are included in the article 9. According to this article, the most important national issues shall be decided by referendum. Referendum may be called by the parliament or if not fewer than 300000 citizens with the electoral right request so. Procedures for calling and conducting referendum are specified in the Lithuanian Republic Law on Referendum. ${ }^{5}$ This act confirms the principle that the most important decisions regarding the State are taken by citizens or parliament. Participation in the referendum is granted to Lithuanian citizens who are eighteen years of age and over, and have full civil rights. Furthermore, all citizens participating in referendum are equal regardless of their sex, nationality, language, religion, beliefs and opinions. The Lithuanian law on referendum distinguishes two types of referendum - mandatory referendum and consultative referendum. The article 4 of this law provides for five cases in which parliament is obliged to conduct a mandatory referendum, three of them are closely connected with the alteration or provision of the amendment to some part of the Lithuanian Constitution (the first article of the first chapter of constitution: "Lithuania is an independent democratic republic" - amendment; the first chapter "The State of Lithuania" and fourteenth chapter "The Alteration of the Constitution" - provision of amendment). Moreover, the obligatory referendum is managed in case of replacement for Constitutional Act "On the Non-Alignment of the Republic of Lithuania to Post-Soviet Eastern Unions" (adopted on 8 June 1992) and for the Republic of Lithuania's participation in international organizations, where such participation is associated with partial transfer of the Lithuanian State bodies competence to international organizations or institutions under their jurisdiction.

According to the Lithuanian Republic Law on Referendum, consultative referendum may be held in any important matter concerning the Lithuanian public life, except in cases covered by the mandatory referendum.

The citizens of the Republic of Lithuania also have the right to legislative initiative. No fewer than 50000 citizens with full public rights may submit the proposal draft of the law to the Seimas, and in this case the Lithuanian Parliament must consider it.

4 The Constitution of the Republic of Lithuania (adopted by the citizens of the Republic of Lithuania in the Referendum on 25 October 1992), No. IX-929, article 4 and article 33.

5 Lietuvos Respublikos Referendumo İstatymas, 2002 m. birželio 4 d. Nr. IX-929. 
There have been twelve referendums in Lithuania since 1990:

1) 1991 - independence from the Soviet Union,

2) 1992 - restoration of the institution of the President of Lithuania,

3) 1992 - immediate withdrawal of Russian troops and compensation for damages from the Soviet Union,

4) 1992 - approving the Constitution of Lithuania,

5) 1994 - Law on Illegal Privatization, Depreciated Deposits, and Broken Laws,

6) 1996 - amendments to the Constitution of Lithuania,

7) 1996 - compensation for lost deposits,

8) 1996 - amendments to the Constitution of Lithuania,

9) 2003 - the membership of Lithuania in the European Union,

10) 2008 - extending the operation of the Ignalina Nuclear Power Plant,

11) 2012 - approving the construction of Visaginas Nuclear Power Plant,

12) 2014 - ban on sale of Lithuanian land to non-citizens.

Republic of Latvia stands out from the other Baltic states, because after it regained its independence, it was decided to restore the constitution from 1922. ${ }^{6}$ In Latvia national referendum is obligatory in seven questions, which are stipulated in the constitution and the Law on Referendum. ${ }^{7}$ Firstly, if the Saiema (the Latvian Parliament) has amendment articles 1 ("Latvia is an independent democratic republic"), 2 ("the sovereign power of the State of Latvia is vested in the people of Latvia"), 3 ("the territory of the States of Latvia, within the borders established by international agreements, consists of Vidzeme, Latgale, Kurzeme and Zemgale"), 4 ("the Latvian language is the official language in the Republic of Latvia. The national flag of Latvia shall be red with a band of white"), 6 ("the Saiema shall be elected in general, equal and direct elections, and by secret ballot based on proportional representation"), 77 ("If the Saeima has amended the first, second, third, fourth, sixth or seventy-seventh Article of the Constitution, such amendments, in order to come into force as law, shall be submitted to a national referendum") of the constitution. Secondly, if the President of Latvia has proposed the dissolution of the Saiema. Thirdly, if the President of Latvia has suspended the proclamation of law for two months and during this period a petition by not fewer than one-tenth of the electorate

6 The Constitution of Republic of Latvia, https://www.cvk.lv/pub/upload_file/2014/ Constitution_2014.pdf.

7 Law on National Referendums, Initiation of Laws and European Citizens' Initiative, adopted by the Saeima on 31 March 1994. 
has been received to put the suspended law to national referendum. Fourthly, if the Saiema has not adopted without changes in its contents a draft of law or a draft of amendment to the Constitution submitted by not fewer than onetenth of the electorate. Fifthly, if Latvia's membership in the European Union must be declared. Sixthly, if substantial changes in the terms of Latvia's membership in European Union must be decided and at least one-half of the Members of Saiema have requested a national referendum on this matter. Seventhly, if not fewer than one-tenth electorate has initiated the recalling of the Saiema. The Latvian constitution in article 73 establishes which issues a referendum may not resolve: "the Budget and laws concerning loans, taxes, custom duties, railroad tariffs, military conscription, peace treaties, declaration of a state emergency and its termination, mobilization and demobilization, as well as agreements with other nations."

Similar to the Lithuanian law, the Latvian legislation guarantees the initiatives of voters. A legislation process may be launched by political parties, coalitions of political parties or a registered association of citizens. According to the Constitution, voters in a number not fewer than one-tenth of electorate have the right to submit to the President a draft of amendment to the Constitution or draft of law and in this situation they're obliged to present the draft to the Saiema. Latvians may initiate a national referendum to recall the Saiema.

Since 1990, eight national referendums have been held in Latvia:

1) 1998 - amendments to the Law on Citizenship;

2) 1999 - amendments to the law "On State Pensions";

3) 2003 - the membership of Latvia in the European Union;

4) 2007 - repeal of amendments to the National Security Law and Law on National Security Institutions;

5) 2008 - amendments to the Constitution of the Republic of Latvia;

6) 2008 - amendments to the law "On State Pensions";

7) 2011 - dissolution of the $10^{\text {th }}$ Saeima;

8) 2012 - amendments to the Constitution of the Republic of Latvia.

The Constitution of the Republic of Estonia, which was adopted in 1992, stipulates that citizens may exercise the power in the State by electing the Riigikogu (the Estonian Parliament) or through referendum (article 56). ${ }^{8}$ However, in contrast to legislations of other Baltic countries, Estonian law does not

\footnotetext{
8 The Constitution of the Republic of Estonia, RT 1992, 26, 349.
} 
provide the right to citizens' initiative. The right to initiate the referendum is guaranteed exclusively for Riigikogu. The procedures for conducting a referendum were included in the Referendum Act. ${ }^{9}$ The national referendum is obligatory if the Parliament submits amendments to Chapter I and Chapter XV of the Constitution. In the case of other amendments to the Constitution or draft laws, the Parliament may order a referendum.

The Estonian Constitution does not allow to submit to referendum questions which are related to budget, taxation, financial obligations of the state, ratification and denunciation of international treaties, the declaration or termination of a state of emergency and national defence (article 106).

The Estonian Parliament have called two national referendum since Estonia regained its independence from Soviet Union:

1) 1992 - approving the new constitution and citizenship,

2) 2003 - the membership of Estonia in the European Union.

\section{Local democracy in practice}

The constitutions and laws of the Baltic countries do not provide for local and regional democracy, especially referendums. For example, in Lithuania such solutions have not been introduced in both the transition period, as well as a new law adopted in 2002. There are not similar solutions in the legislation of Latvia and Estonia. However, in all Baltic countries the importance of public opinion is highlighted. Some kind of substitutes of direct democracy are guaranteed by laws relating to local government. According to the Lithuanian Law of Territorial Planning and the Law of Territorial Administrative Units of the Republic of Lithuania and their Boundaries, municipal authorities are required to consult any significant change with inhabitants. Latvia is the only Baltic country in which citizens have the right to initiate a referendum. In practice, the regulation are not citizen-friendly, so the institutions of direct democracy on the local level are not very popular.

Estonia has the most experience with direct democracy at the local level. The first local referendum in Estonia was held in 1927 and it was guaranteed with the Law on Alcoholic Beverage. In 2004 the local referendum was conducted in Tallinn. The issue which was submitted to referendum was the

\footnotetext{
9 Referendum Act, RT I 2002, 30, 176.
} 
limitation of night-time sale of alcohol. At the same year inhabitants of Tallinn initiated referendum on reduction of local fees.

Another example of direct democracy at the local level in Estonia were referendums which were conducted in the Ida-Viru county. Ida-Viru is one of fifteen counties in Estonia and it is the most north-eastern part of the country. By ethnic origin the province is significantly different from other parts of Estonia. Before the Second World War Estonians made up approximately $80 \%$ of population. The situation dramatically changed after the war, because native Russians were not allowed to return to the USSR. In consequence, the number of Russians increased from $29.5 \%$ in 1940 to $85 \%$ in 1989 . The independence movement in Ida-Viru county had been created in the early 90s. It was a response to the exclusion of the Russian intelligentsia from Estonian political system. As Melvin concluded: "The struggle that developed between Tallinn and the cities of the northeast in 1992-93 was thus due to a complex mix of anti-market sentiment, pro-Soviet sympathy, a centre-region struggle and degree of ethnic-base anxiety." ${ }^{10}$ The referendum was planned in three cities: Narva, Kohtla-Järve and Sillamäe. Finally, it was held only in Narva and Sillamäe, because municipal authorities refused to organize referendum in Kohtla-Järve. The Narva City Council decided to hold a referendum in Narva on the 16 and 17 July 1993, posing the following question: "Do you want Narva to have the status of a national-territorial autonomy within the Republic of Estonia?" The referendum was conducted on 16 and 17 July 1993. In Narva the turnout was $57.4 \%$ and approximately $97 \%$ eligible voters supported the autonomy. Similar results were obtained in Sillamäe: the turnout was $61 \%$ and $98 \%$ voters opted to autonomy. ${ }^{11}$ What is important, referendums in Ida-Viru county were illegal and they were contrary to the regulations of the Estonian Constitution. The final decision on the validity of the referendums has been taken by the Supreme Court of Estonia. The conclusion of decision announced on 11 August 1993 stated: "To satisfy the petition of the Chancellor of Justice of the Republic of Estonia no. 1 of 20 July 1993 , and to declare the Narva City Council resolution no. 15/163 of 28 June 1993, entitled 'The opinion on the Foreigners Act,' invalid in its entirety." 12

${ }^{10}$ N. Melvin, Russians beyond Russia. The Politics of National Identity, London: Chatam House Papers, 1995, 48.

11 D. J. Galbreath, "Nation-Building and Minority Politics in Post-Socialist States. Interests, Influences and Identities in Estonia and Latvia," in: Soviet and Post-Soviet Politics and Society, ed. A. Umland, Stuttgart \& Hannover: Ibidem Verlag, 2005, 162.

12 Judgment Of The Constitutional Review Chamber Of The Supreme Court Of 11 August 1993. Review of the petition of the Chancellor of Justice under $\$ 142(2)$ of the 
Legislation of the Baltic countries provide a direct democracy at the national level. National referendum is the most widely used institution of direct democracy in Lithuania, Latvia and Estonia. What is important, constitutions and laws do not regulate the issues of direct democracy at the local level. The possibility of citizens' direct participation in decision-making is provided by the laws of self-government and local administration.

The weakness of local direct democracy in the Baltic republics is the consequence of lack of citizens' interest in public affairs, as well as the decline of public participation. Another issue is that local authorities have not introduced their own regulations on referendums. ${ }^{13}$

Constitution for the declaration of invalidity of the Narva City Council resolution no. 15/163 of 28 June 1993, entitled "The opinion on the Foreigners Act."

13 J. Ruus, "Democratic Participation at the Local Level in Post-communist States: Estonia, Latvia, Lithuania," in: Local Direct Democracy in Europe, ed. T. Schiller, Wiesbaden: Springer Fachmedien, 2011, 276. 